\title{
Genetic Relationships between Lifetime Profit and Type Traits in Spanish Holstein Cows
}

\author{
M. A. Pérez-Cabal and R. Alenda \\ Departamento de Producción Animal, \\ E.T.S.I. Agrónomos - Universidad Politécnica, \\ Ciudad Universitaria $\mathrm{s} / \mathrm{n}$, \\ 28040 Madrid, Spain
}

\section{ABSTRACT}

Genetic parameters and relationships were estimated for profit and type traits for Spanish Holstein cows. In this study, 46,316 cows with official production and type data from Navarra and Basque autonomous regions of Spain were used to calculate profit per cow and year of productive life. Data from 239 Basque Autonomous Region herds in year 1995 were considered to obtain average prices system for yield, meat, feeding, and housing costs. An average cow had a net profit of 78.56 euros per year of productive life, with $7334 \mathrm{~kg}$ of milk, 3.85 lactations and 28.0 mo of age at first calving. Heritability of profit was 0.25 . Genetic correlations between profit and almost all conformation traits were low to moderate, from 0.12 for leg side view to 0.37 for suspensory ligament while stature, body depth, and udder depth had close to zero correlations with profit. Significant quadratic relationships were found between breeding values for profit and feet and legs, foot angle, fore-udder attachment, rear-udder height and udder depth. The most influential type trait on profit adjusted for production was feet and legs. Animals with negative breeding values for legs were not less profitable than another with zero value, but positive values increased profit per cow and year with a quadratic and positive relationship. Other traits affecting profit out of production and longevity, such as fertility and mastitis, should be considered in future studies.

(Key words: lifetime profit, type trait, genetic, quadratic relationship).

Abbreviation key: $\mathbf{B V}=$ breeding value, $\mathbf{D P L}=$ days of productive life.

\section{INTRODUCTION}

The breeding goal in dairy cattle is to increase lifetime profit per animal and unit of time. Profit is a func-

Received February 28, 2002.

Accepted July 1, 2002.

Corresponding author: M. A. Pérez-Cabal; e-mail: maperez@ pan.etsia.upm.es. tion of production and the time that a cow remains in herd. Thus, profit can only be recorded when a cow is culled, and the selection of more profitable animals should be able to be predicted by indexes from measurements at an early age of the cow. These indexes can be developed by two ways: 1) One way is where the importance of each trait is established by breeder consensus, based on expected genetic response, to obtain a type-production index (e.g., LPI, TPI, ICO, etc.). 2) The other way takes into account the economic circumstances of the production system to obtain the economic weights of the traits involved in the breeding goal. Both kinds of indexes use production traits to estimate productivity and conformation traits (generally, udder traits and feet and legs) related to herd life with the aim of indirectly predicting functional longevity (Vollema, 1998).

Traditionally, selection indexes are a linear combination of breeding values (BV) of production and conformation traits, because linear relationships between profit and those traits were supposed. Some studies relating to conformation traits deal with genetic relations with production traits and herd life for inclusion in a selection index (e.g., Klassen et al., 1992; Short and Lawlor, 1992; Weigel et al., 1998). Other authors directly studied phenotypic and genetic relationships between type and longevity, some including the possibility of finding nonlinear relations (Rogers et al., 1991; Burke and Funk, 1993; Visscher and Goddard, 1995b; Vukasinovic et al., 1995; Larroque and Ducrocq, 1999; Sölkner and Petschina, 1999). However, few studies relating to the relationship of type traits with profit are published. Some studies of genetic parameters of lifetime profit and conformation exist (Cassell et al., 1990; Visscher and Goddard, 1995a; Pérez et al., 1999), but only Norman et al. (1996) reported quadratic phenotypic relationships between some linear-type traits and profit and suggested the analysis of the possible quadratic genetic relationships.

The purpose of this study was to examine genetic relationships between conformation traits and profit in a Holstein population by estimating genetic parameters 
and linear and quadratic regressions between BV of profit and days of productive life (DPL) with type traits.

\section{MATERIALS AND METHODS}

\section{Data}

Historical type and milk yield data up to May 2000 of 135,200 cows from Navarra and the Basque Autonomous Regions of Spain were provided by the Spanish Holstein Association (CONAFE) official type classification and milking recording system. To obtain adequate datasets for the statistical analyses, original records were taken with several restrictions and 46,316 cows with lactations between 1979 and 2000 constituted the final data set. All animals had to belong to herds with continuous milking records during a minimum of $4 \mathrm{yr}$ in order to have at least $4 \mathrm{yr}$ of productive life. First calving was required to be before May 1996, and the animal had to be between 18 and 40 mo of age at such time. Calving interval had to range between 300 and $550 \mathrm{~d}$ and a maximum of 10 lactations per cow was considered. Lifetime variables included for each cow were number of lactations, lifetime milk yield, fat yield, and protein yield (sum of actual yield across lactations), DPL (defined as the interval between first calving and last day of the final lactation), lifetime days in lactation (defined as the sum of days in milking of all lactations), average interval between successive calving, age at first calving, and profit per year of productive life.

Economic data used were from the average values of 239 Basque autonomous region herds for 1995 (Charfeddine, 1998), even though all herds considered in the study have similar production systems and market conditions. Economic information included milk price, bonuses and penalties for milk quality, calf price, culled cow salvage value, food costs for heifers and cows, and other yearly costs such as veterinary, medicine, labor, housing. Average values for calf, heifer, and cow mortality for those 239 herds were applied. Type traits BV were from the CONAFE evaluation of February 2000. Scores for 14 type traits were combined in accordance with animal milk yield and lifetime variables to avoid incomplete records. Eight standard type traits describing body conformation (stature and body depth), feet and legs (foot angle and leg side view) and udder morphology (fore-udder attachment, rear-udder height, suspensory ligament and udder depth), and six general traits (feet and legs, mammary system, capacity, dairy character, rump, and final score) were used. In the Spanish classification system, the classifier scores the general traits (except final score) on a scale from 1 to 18. Final score is obtained by combining the five general traits: mammary system (40\%), capacity (20\%), feet and legs (16\%), dairy character (14\%), and rump (10\%).

\section{Profit per Year of Productive Life}

A compound of production and longevity defines the biological portion of profit per cow. The offspring will receive a genetic merit for profit from the genetic merit of their parents for surviving a long time in herd avoiding voluntary and involuntary culling (low production, bad reproductive aptitude, health problems, and leg diseases).

Profit per cow and year was defined as the difference between returns and costs per year of productive life, with returns $(\mathrm{R})$ and costs $(\mathrm{C})$ as follows,

$$
\begin{gathered}
\mathrm{R}=[\mathrm{LMP} \times \mathrm{MP}+\mathrm{NL} \times(1-\mathrm{CM}) \times \mathrm{CP}+\mathrm{SV}] \times \frac{365}{\mathrm{DPL}} \\
\mathrm{C}=\left(\mathrm{FCH}+\mathrm{OCH} \times\left(\frac{1}{1-\mathrm{HM}}\right)+\mathrm{CP}+\mathrm{FCC}+\mathrm{OCC}\right) \\
\times \frac{365}{\mathrm{DPL}}
\end{gathered}
$$

where, LMP is lifetime milk production, MP is milk price, including bonuses and penalties for fat and protein, NL is number of lactations, CM is calf mortality, $\mathrm{CP}$ is calf price, DPL is days of productive life, SV is the culled cow salvage value, $\mathrm{FCH}$ is heifer food costs, $\mathrm{OCH}$ is other costs related to rearing a heifer (veterinary, labor, housing...), HM is heifer mortality, FCC is cow food costs, OCC is other cow costs. If a cow did not have a productive life greater than $365 \mathrm{~d}$, its returns and costs were not corrected by the term 365/DPL and they were considered as the actual value. Food costs for heifers and cows were obtained from energy requirements at different physiological stages (growth, maintenance, pregnancy and lactation) taking account for the BW and production levels, following Charfeddine (1998) procedures. Individual BW was calculated from its size score classification, age, and live weight using the Von Bertalanffy method (Korver et al., 1985).

\section{Estimation of Genetic Parameters}

Heritabilities and genetic correlations between profit and type traits were calculated by REML using the VCE 4.0 software (Groeneveld and García Cortés, 1998). A multiple trait analysis for profit and each type trait was performed. Fixed effects were herd-year of first calving (with 5,969 classes) for the profit model, and herd-round-classifier (with 5,808 classes), lactation-age at classification (three classes) and stage of lactation (11 classes) for type traits model. Random effects included in both models were the animal additive genetic value and residual. A dataset of 42,401 cows was extracted from the 46,316 animals file to estimate genetic parameters because a minimum of three animals by 
Table 1. Means and standard deviations (SD) of profit, production, and type traits.

\begin{tabular}{|c|c|c|}
\hline & Mean & SD \\
\hline Profit (euros/cow per year) & 78.56 & 329.99 \\
\hline Age at first calving (mo) & 28 & 4 \\
\hline Number of lactations & 3.85 & 1.93 \\
\hline Calving interval (d) & 406 & 49 \\
\hline Lactation days (per lactation) & 324 & 60 \\
\hline Days of productive life & 1458 & 769 \\
\hline Milk per lactation $(\mathrm{kg})$ & 7334 & 2321 \\
\hline Fat per lactation $(\mathrm{kg})$ & 276 & 89 \\
\hline Protein per lactation (kg) & 227 & 76 \\
\hline Final score ${ }^{1}$ & 76.5 & 3.8 \\
\hline Dairy character ${ }^{2}$ & 9.5 & 2.1 \\
\hline Rump $^{2}$ & 8.8 & 2.1 \\
\hline Capacity $^{2}$ & 9.8 & 2.6 \\
\hline Stature $^{3}$ & 6.0 & 1.5 \\
\hline Body depth ${ }^{3}$ & 5.6 & 1.4 \\
\hline Feet and legs ${ }^{2}$ & 8.4 & 2.3 \\
\hline Foot angle $^{3}$ & 5.1 & 1.4 \\
\hline Leg side view ${ }^{3}$ & 5.7 & 1.2 \\
\hline Mammary system $^{2}$ & 8.1 & 2.1 \\
\hline Fore-udder attachment ${ }^{3}$ & 4.9 & 1.2 \\
\hline Rear-udder height ${ }^{3}$ & 5.1 & 1.2 \\
\hline Suspensory ligament ${ }^{3}$ & 5.7 & 1.4 \\
\hline Udder depth ${ }^{3}$ & 5.2 & 1.4 \\
\hline
\end{tabular}

${ }^{1}$ Scale 62 to 90.

${ }^{2}$ Scale 1 to 18 .

${ }^{3}$ Scale 1 to 9 .

contemporary group condition was imposed (herd-year of first calving for the profit model and herd-roundclassifier for the type traits model). Profit BV estimates were calculated using the same model as above, but in a single-trait analysis.

\section{Estimation of Regression Coefficients}

Regressions between estimated BV of profit and 14 type traits were estimated using the general linear models (GLM) procedure of the statistical package SAS (SAS, 1998). Milk, fat, and protein BV in kilograms from the February 2000 CONAFE evaluation were used as covariates in the model in order to analyze the relationship between each type trait and profit regardless of production. This adjustment for production is a way to analyze influence of type in profitability throughout functional longevity; therefore regressions between days of productive life BV (also regardless of production) and conformation were also studied to aid in graphic interpretation.

\section{RESULTS AND DISCUSSION}

\section{Means and SD of phenotypic traits}

Profit, production and type trait means and standard deviations are shown in Table 1 . An average cow of the population studied (from year 1979 to 2000) had its first calving at 28 mo of age and a total of 3.85 lactations. The period between two consecutive freshenings was $406 \mathrm{~d}$, with $324 \mathrm{~d}$ in milking per lactation and an average of $7,334 \mathrm{~kg}$ milk per lactation. Average profit obtained was 78.56 euros $(€)$ per cow and year and values for all dataset ranged from -1094.53 to 2449.13 ( $€ /$ cow per year). Pérez et al. (1999) used the same profit function, but the value of profit obtained was higher (410.64 €/cow per year), possibly due to a smaller dataset used with animals throughout a narrower year interval and more closely tied to the economic circumstances of year 1995. Average standard type scores were similar in both studies, with stature and fore-udder attachment as highest and lowest, respectively.

Table 2 shows means and standard deviations for the returns and costs of the population studied. Returns from an average cow were $1733.54 €$ /year from milk sale, 184.81 euros/year from calf sale, and $258.37 € /$ year from culling. Those values were calculated for each cow, while the other costs for heifers $(\mathrm{OCH})$ and other costs for cows (OCC) used to obtain profit were the average costs from 239 herds from Basque Autonomous Region in 1995 (287.81 €/heifer and $530.32 € /$ cow per year, respectively).

\section{Genetic Parameters}

Heritability. Heritabilities and genetic correlations calculated between profit and type traits are shown in Table 3. Moderate heritability was obtained for profit (0.25). This result is greater than the 0.09 presented by Pérez et al. (1999) (perhaps due to the smaller sample used in their study) and the 0.13 for the Australian Holstein in a pasture production system (Visscher and Goddard, 1995a). Heritability for type traits was between 0.11 for foot angle and 0.43 for stature. In accordance with other studies, the highest heritabilities were for capacity and body conformation traits, followed by dairy character and udder traits, while rump and feet

Table 2. Means and standard deviations (SD) of returns and costs $(€ /$ cow per year) for the population studied.

\begin{tabular}{|c|c|c|}
\hline & Mean & SD \\
\hline \multicolumn{3}{|l|}{ Returns } \\
\hline Milk & 1733.54 & 431.46 \\
\hline Calf & 184.81 & 27.66 \\
\hline Culling & 258.37 & 167.57 \\
\hline \multicolumn{3}{|l|}{ Costs } \\
\hline Cow feeding & 1133.63 & 134.14 \\
\hline Heifer feeding* & 734.19 & 97.13 \\
\hline Other costs for cows ${ }^{1}$ & 530.32 & - \\
\hline Other costs for heifers ${ }^{* 1}$ & 287.81 & - \\
\hline
\end{tabular}

$* € /$ heifer.

${ }^{1}$ Average from 239 herds from Basque Autonomous Region in year 1995. 
Table 3. Heritability and genetic correlations between profitability and type traits.

\begin{tabular}{lll}
\hline & Heritability $^{1}$ & Genetic correlation \\
\hline
\end{tabular}

\footnotetext{
${ }^{1}$ Approximate standard errors were 0.01 for all heritabilities.

${ }^{2}$ Standard errors of genetic correlations ranged between 0.01 and 0.04 .
}

and leg traits obtained lowest values. The final score had a moderate heritability (0.29), slightly higher than the 0.25 reported in Charfeddine (1998) but similar to the results obtained by Brotherstone et al. (1990), Short and Lawlor (1992), Visscher and Goddard (1995b) and Pérez et al. (1999), with heritabilities above 0.26. For final score, capacity and dairy character, Schaeffer (1983) and Klassen et al. (1992) obtained lower values. The heritability obtained for rump was intermediate between values in Schaeffer (1983) and Klassen et al. (1992). Stature was the type trait with the highest heritability in agreement with other studies that also found values greater than 0.40 . Body depth had 0.32 , although in the literature slightly higher results were reported (Weigel et al., 1998). Moderate heritability was obtained for udder traits, ranging from 0.18 for fore-udder attachment to 0.27 for rear-udder height. Previous works found similar results. Foot angle, feet and legs, and leg side view had the lowest heritabilities $(0.11$, 0.12 , and 0.17), respectively. Thompson et al. (1981) obtained the highest heritability for leg side view (0.24) among consulted results.

Genetic correlations. Almost all the genetic correlations between profit and type traits were positive, except for body depth and udder depth (Table 3), and the correlation between profit and rump, stature, and capacity was almost null $(0.02,0.06$, and 0.03 , respectively). Pérez et al. (1999) also found negative correlations, but theirs were more pronounced. This could mean that large animals would have higher feeding demands, which would mean either an increase of costs or fertility problems if feeding demands were not supplied, because the calving interval could be increased and, as a consequence, days in lactation would be fewer.
Agreeing with this idea, Pérez et al. (1999) found a correlation of 0.76 between profit and days in lactation, and then, that cows with long lactation periods are more profitable. Cassell et al. (1990) found a negative correlation between profit and body depth in sire evaluations for grade and registered daughters, but a slightly positive one with udder depth. Results obtained for udder depth could be misleading because of the influence of level of production. High-yielding cows have deeper udders (Meyer et al., 1987; Norman et al., 1988), and this could cause sanitary problems, which influence the longevity of the animal (Larroque and Ducrocq, 1999). The negative correlations of our study are close to zero and assert that apparently no correlation exists between profit and rump, capacity, body depth, stature, or udder depth would be an objective conclusion for these traits. However, the relationship of profit BV to udder depth showed later in this study suggests other conclusions.

Moderate correlations were obtained for udder traits (except udder depth). They ranged from 0.22 for foreudder attachment to 0.37 for suspensory ligament. Cassell et al. (1990) described lower correlations but, there too, udder cleft was the most correlated type trait with profit. These results suggest that a tightly held and conformed udder withstands a high level of production, reduces the risk of some diseases and the cow, therefore, is more profitable.

The correlation with the final score was 0.28 and the rest of type traits obtained lower values than udder traits. Body traits had the lowest correlations with profit, close to zero. Leg traits had a low correlation with profit, but with positive values possibly due to their relationship to longevity. McDaniel (1997) reported higher claw angles were positively correlated with increased survival, as was also rear legs view. Choi and McDaniel (1993) found a genetic correlation between claw angle and age at culling of 0.87 , in accordance with the affirmation that after reproduction, low yield and mastitis, foot and leg problems and locomotive disorders are the most significant reason for involuntary culling. As in our study, some researchers found positive genetic correlations between leg side view and profit (Cassell et al., 1990; Dekkers et al., 1994). It is difficult to explain this result because this is an intermediate optimum trait.

The results obtained in this study about heritabilities and genetic correlations are consistent with the literature despite the small dataset used (compared with the whole Spanish Holstein population). Therefore, they support the results from the following works shown in this study. 
Table 4. Significant linear (L) and quadratic (Q) regression coefficients for prediction of breeding value of profit from breeding values of individual type traits, when production traits were or not considered as covariates (adjusted and unadjusted model, respectively).

\begin{tabular}{|c|c|c|c|c|c|c|}
\hline \multirow[b]{2}{*}{ Type trait } & \multicolumn{3}{|c|}{ Adjusted model } & \multicolumn{3}{|c|}{ Unadjusted model } \\
\hline & $\mathrm{L}^{1}$ & $\mathrm{Q}^{2}$ & $\Delta^{3}$ & $\mathrm{~L}^{1}$ & $\mathrm{Q}^{2}$ & $\Delta^{3}$ \\
\hline Final score & $4.75^{* *}$ & $1.01^{*}$ & +0.0002 & $23.81^{* *}$ & $1.54^{* *}$ & +0.0006 \\
\hline Dairy character & $4.13^{* *}$ & $1.84^{* *}$ & +0.0007 & $33.23 * *$ & $4.86^{* *}$ & +0.0047 \\
\hline Rump & $-1.89 * *$ & $0.64 \dagger$ & +0.0001 & $4.98 * *$ & $7.44^{* *}$ & +0.0073 \\
\hline Capacity & $-2.35^{* *}$ & $0.57 \dagger$ & +0.0001 & $11.62 * *$ & $1.56^{* *}$ & +0.0004 \\
\hline Stature & $-1.93 * *$ & $0.65^{*}$ & +0.0001 & $11.35^{* *}$ & $1.16^{*}$ & +0.0002 \\
\hline Body depth & $-4.54 * *$ & $1.44^{* *}$ & +0.0002 & $10.09 * *$ & $5.02 * *$ & +0.0027 \\
\hline Feet and legs & $11.04 * *$ & $5.71 * *$ & +0.0029 & $26.11^{* *}$ & $13.85^{* *}$ & +0.0174 \\
\hline Foot angle & $8.19 * *$ & $4.22 * *$ & +0.0012 & $16.67 * *$ & $16.20 * *$ & +0.0180 \\
\hline Leg side view & $-2.28 *$ & $-1.09 *$ & +0.0001 & $5.19 * *$ & $3.63 * *$ & +0.0014 \\
\hline Mammary system & $5.59^{* *}$ & NS & - & $25.25^{* *}$ & $1.04 *$ & +0.0001 \\
\hline Fore-udder attachment & $3.50^{* *}$ & $-1.02 *$ & +0.0001 & $19.06^{* *}$ & $1.51^{*}$ & +0.0001 \\
\hline Rear-udder height & $3.78^{* *}$ & $3.17 * *$ & +0.0012 & $24.35^{* *}$ & $5.36^{* *}$ & +0.0035 \\
\hline Suspensory ligament & $8.00^{* *}$ & $1.07 *$ & +0.0002 & $28.59 * *$ & $4.95^{* *}$ & +0.0024 \\
\hline Udder depth & $4.34^{* *}$ & $1.14 \dagger$ & +0.0001 & $-13.22^{* *}$ & $12.26^{* *}$ & +0.0089 \\
\hline \multicolumn{7}{|l|}{$\dagger P<0.10$} \\
\hline \multicolumn{7}{|l|}{$* P<0.01$} \\
\hline \multicolumn{7}{|l|}{$* * P<0.0001$} \\
\hline \multicolumn{7}{|c|}{${ }^{1}$ Linear regression coefficient in the first-order model. } \\
\hline \multicolumn{7}{|c|}{$\begin{array}{l}{ }^{2} \text { Quadratic regression coefficient in the second-order model containing linear and quadratic effects for } \\
\text { each type trait. }\end{array}$} \\
\hline \multicolumn{7}{|c|}{$\begin{array}{l}{ }^{3} \text { Increase in coefficients of determination, represents the difference between regression coefficients of } \\
\text { determination }\left(\mathrm{R}^{2}\right) \text { of the second-order and first-order models. }\end{array}$} \\
\hline
\end{tabular}

\section{Linear and Quadratic Regressions}

Significant regression coefficients and the increases in coefficients of determination $\left(\mathrm{R}^{2}\right)$ of the models, after the inclusion of the quadratic term, when production traits were or not considered as covariates, are in Table 4. Zero profit has been obtained for a zero BV of each type trait in the linear regression. All significant models adjusted for production traits BV had a similar $\mathrm{R}^{2}$ (50 to $51 \%$ ), while in unadjusted models $\mathrm{R}^{2}$ only ranged from $1 \%$ (for body depth and rump) to $16 \%$ (for dairy character). In general, increases in coefficients of determination were low in both kinds of models, but smaller increases were found in adjusted profit.

Significant quadratic coefficient was found for final score and rump, but the increase in $\mathrm{R}^{2}$ was so low (0.0002 and 0.0001 , respectively), that their relationships with profit BV could be considered as linear (Figure 1). Only animals with the higher breeding values for dairy character are slightly more profitable.

Body traits. Figure 2 shows significant linear and quadratic relationships between profit and DPL BV with capacity, stature, and body depth. Size traits BV had very little influence on the profit BV. For body traits, models had a significant quadratic adjustment but with a small $\mathrm{R}^{2}$ increase. Animals with high body depth values (large animals) are slightly less profitable than animals with negative BV, but they will not transmit a negative profit because it is close to zero. This is in agreement with the almost null genetic correlations found for these traits with profit. However, Figure 2d and $f$ show that tall and deep animals remain for less time in herd. The same analysis was made with profit without considering production traits BV in the model, and size traits and different results were found. In this case, the body depth trend was positive for linear and quadratic statistical adjustments, for stature as well, and the increase in $\mathrm{R}^{2}$ for body depth was higher than the model with production traits, meaning that larger cows were the most profitable (Figure 3a). But larger animals remain for less time in herd than smaller ones (Figure 3b); then maybe a balance between returns from high yield and costs from higher feeding requirements occurs because of the high correlation between size and production (Short and Lawlor, 1992).

Locomotive traits. Figure 4 shows significant linear and quadratic relationships between profit and DPL with locomotive traits BV. A quadratic model better explained the relationship between feet and legs and foot angle with profit BV, while leg side view can be considered as linear. The range of the curve went from slightly negative values to almost $60 € /$ cow per year. Figure 4a shows that an animal with a feet and legs BV of -2 (generally considered by producers as bad legs), and another one with a BV of 0 will transmit an almost zero profit per cow and year. In other words, animals with low BV for feet and legs will not deterio- 

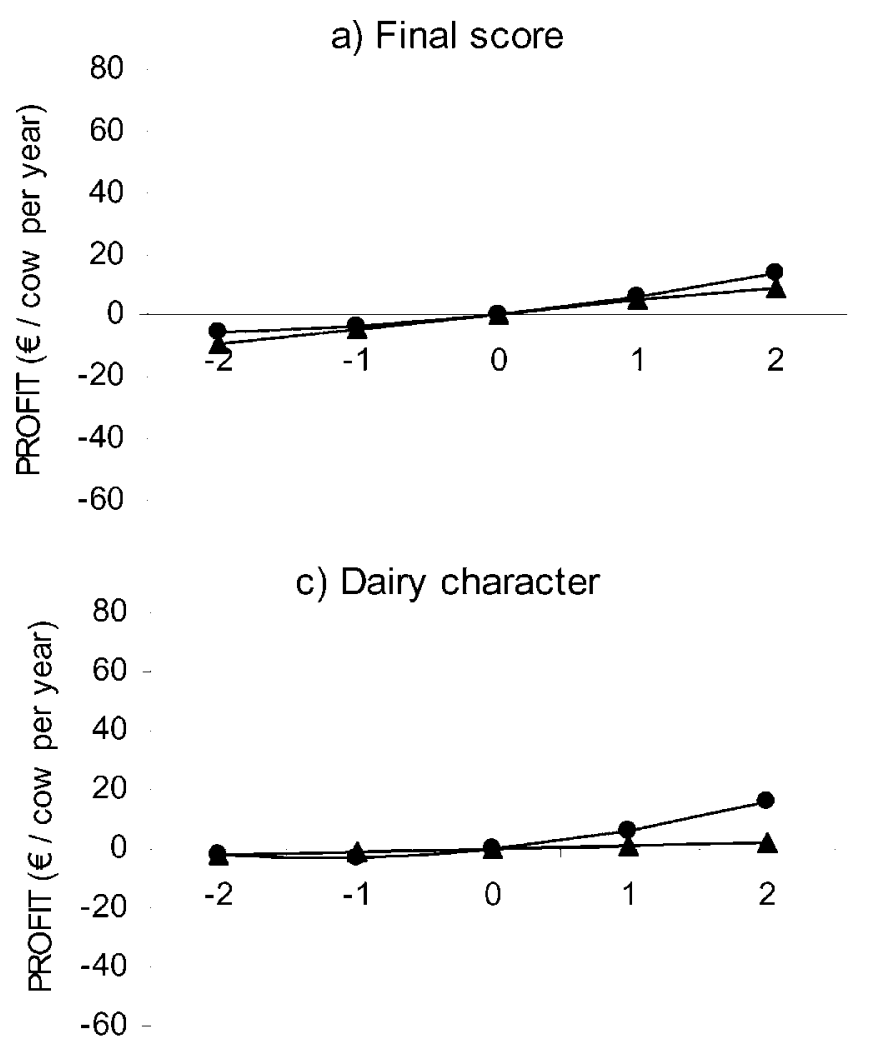

e) Rump

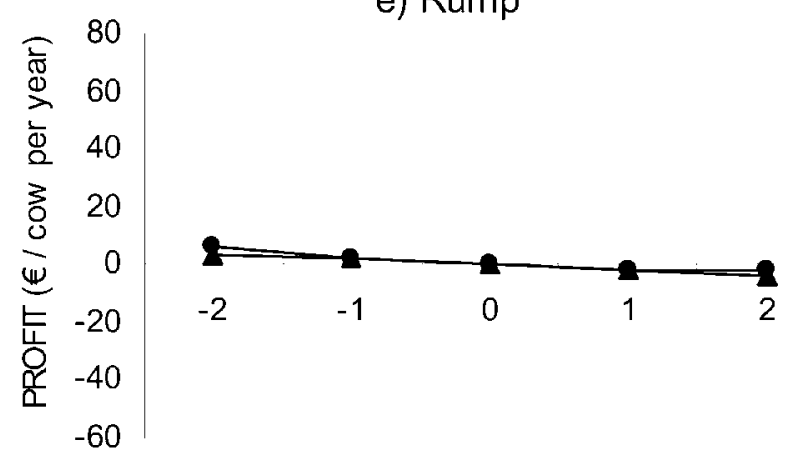

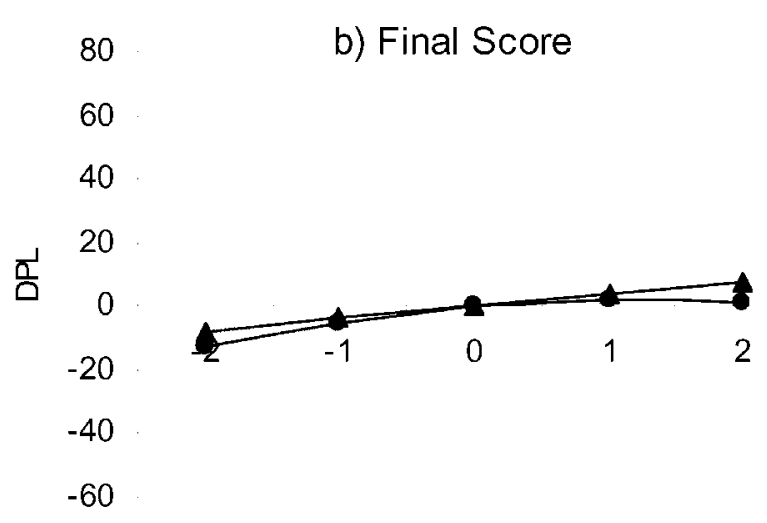

d) Dairy character
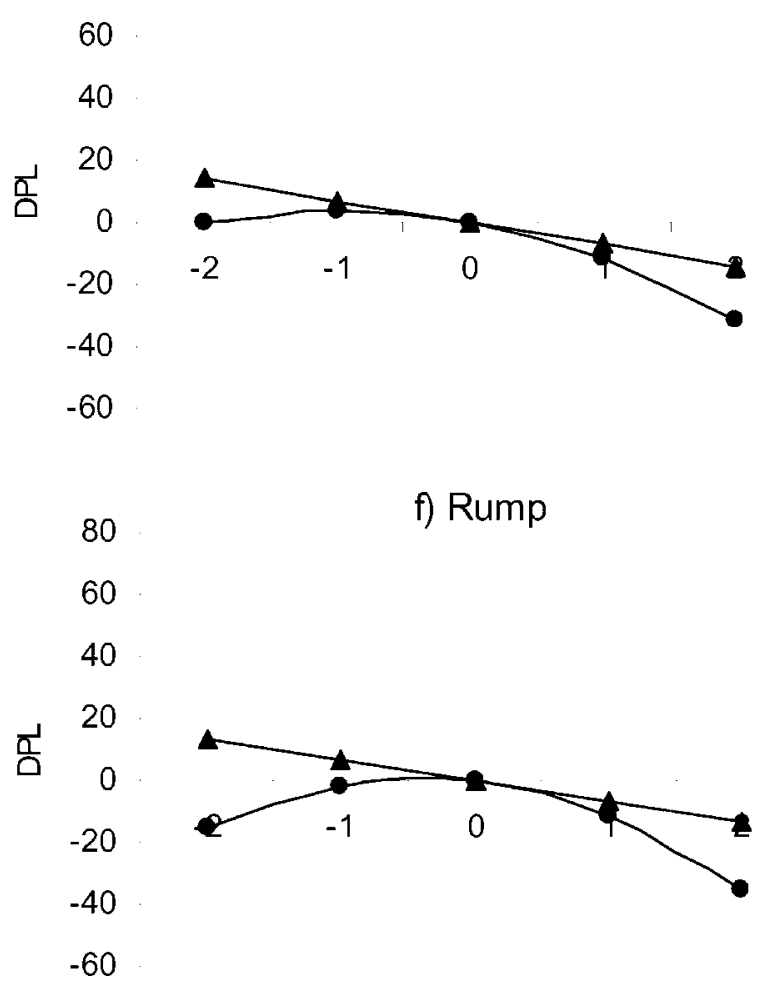

Figure 1. Significant linear (A) and quadratic ( ) relationships between breeding values of profit (euros per cow and year) and days of productive life (DPL) adjusted for production traits, with final score, dairy character, and rump breeding values.

rate their offspring profit, as would be concluded if only a linear regression was considered. Therefore, the profit of such animals has been underestimated. However, positive BV for feet and legs and foot angle can improve profit with a more noticeable trend. For instance, a bull with $+2 \mathrm{BV}$ will transmit three times more profit than a bull with a BV of +1 (half of $43 €$ vs. half of $13 €$ per daughter and year, respectively). For leg side view, its influence on profit was minimal (Figure 4e), and negative linear and quadratic coefficients were found sig- nificant, but the quadratic adjustment was important with DPL (Figure 4f), showing that it is an intermediate optimum trait.

Despite the strong quadratic adjustment for predicting profit by feet and legs and foot angle BV, their relation to DPL is basically linear (Figure $4 \mathrm{~b}$ and d). Negative feet and legs BV reduced longevity. This meant that an animal with bad legs had a major effect on longevity but not on final profit. The differences in the shapes of the curves between the locomotive traits 

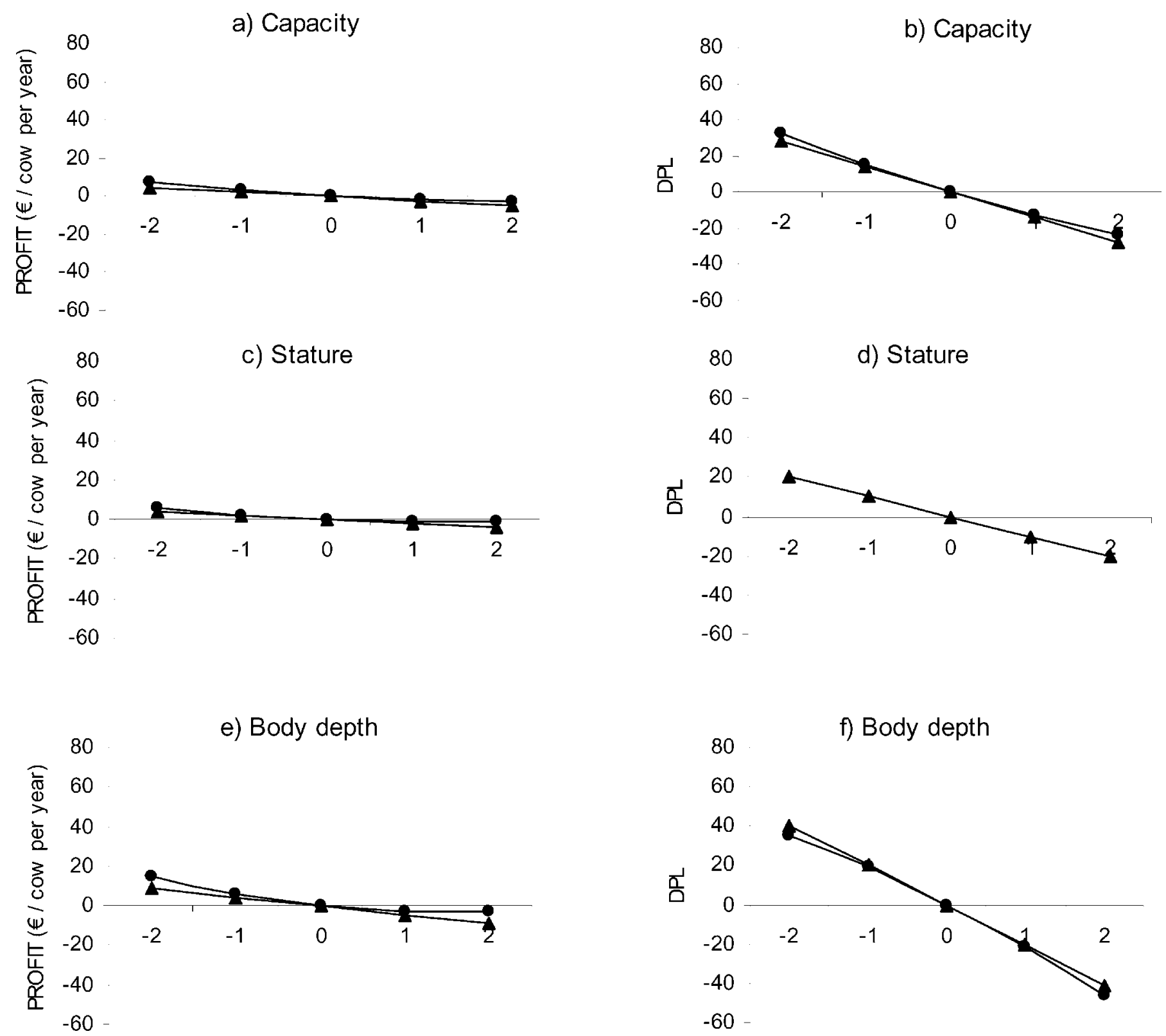

Figure 2. Significant linear $(\mathbf{\Delta})$ and quadratic $(\bullet)$ relationships between breeding values of profit (euros per cow and year) and days of productive life (DPL) adjusted for production traits, with body traits breeding values.

with profit and DPL suggest that other traits with significant effects on profit (apart from longevity and production) are involved and overcome the effect of negative legs BV on longevity, probably fertility, through age at first calving or total days in milk, which is highly correlated with profit (0.76) (Pérez et al., 1999). Roxström and Strandberg (2002) concluded that functional longevity should be divided into three components: production, mastitis and fertility, and in this study neither fertility or mastitis has been considered as a trait. When these relationships were studied without production adjustment (Figure 3c and d), results were similar and both traits had the highest increases in $\mathrm{R}^{2}$.

Leg traits were the most important among all type traits studied when profit had been predicted regardless of production, despite the low genetic correlation obtained in this study and in the literature, possibly because genetic correlations are estimated assuming linear regression and for the population studied it has been shown that quadratic relations exist.

Udder traits. Mammary system, as an overall udder trait, had a positive linear relationship with profit (Fig- 
a) Body Depth

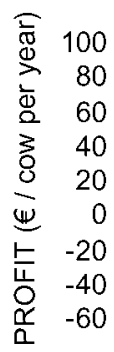

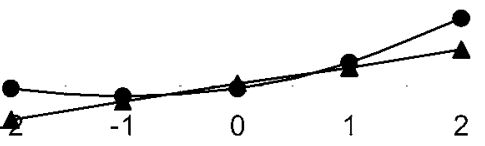

c) Feet and Legs

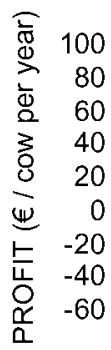

e) Mammary System
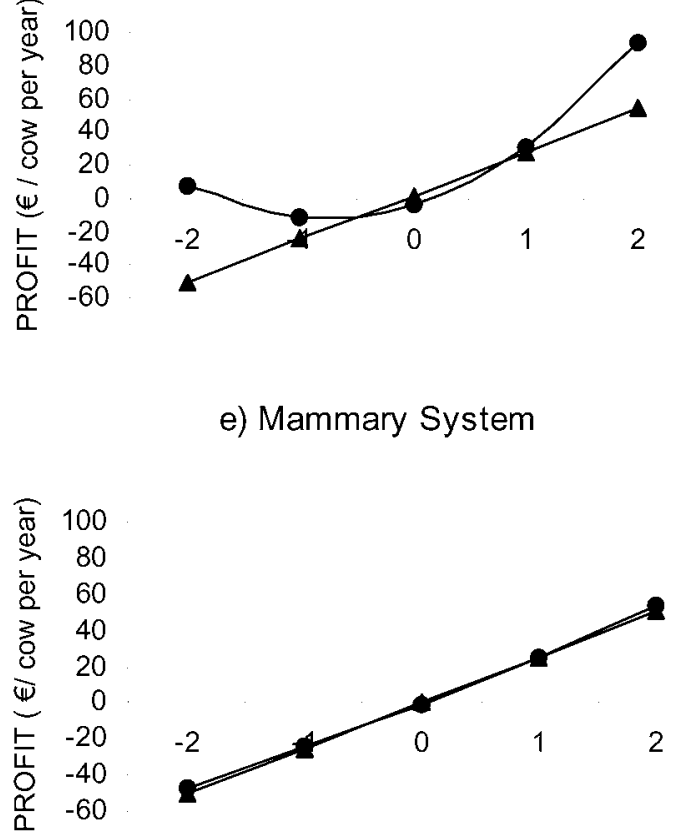

g) Udder Depth

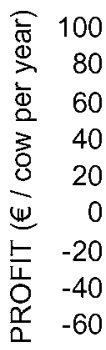

b) Body Depth
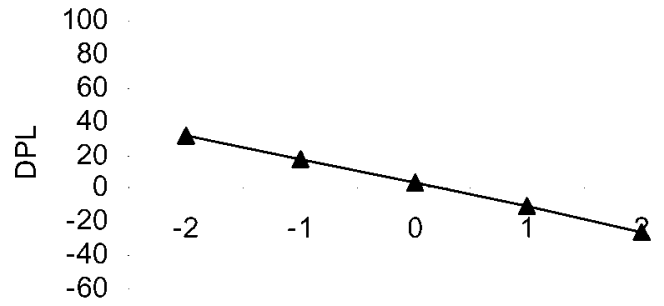

d) Feet and Legs

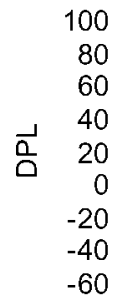

f) Mammary System

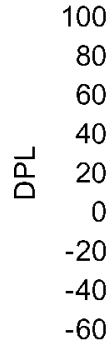

h) Udder Depth

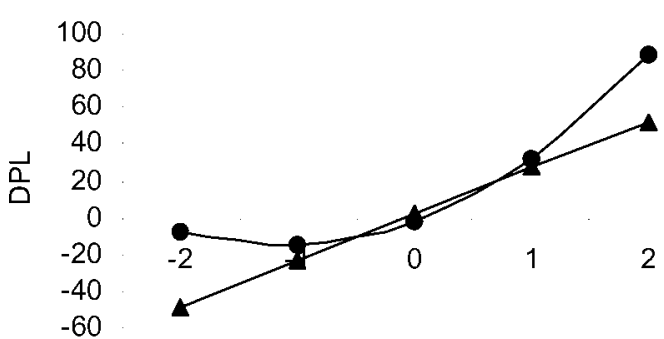

Figure 3. Significant linear $(\boldsymbol{\Delta})$ and quadratic (-) relationships between breeding values of profit (euros per cow and year) and days of productive life (DPL) with four type traits breeding values without considering production traits breeding values in the model. 

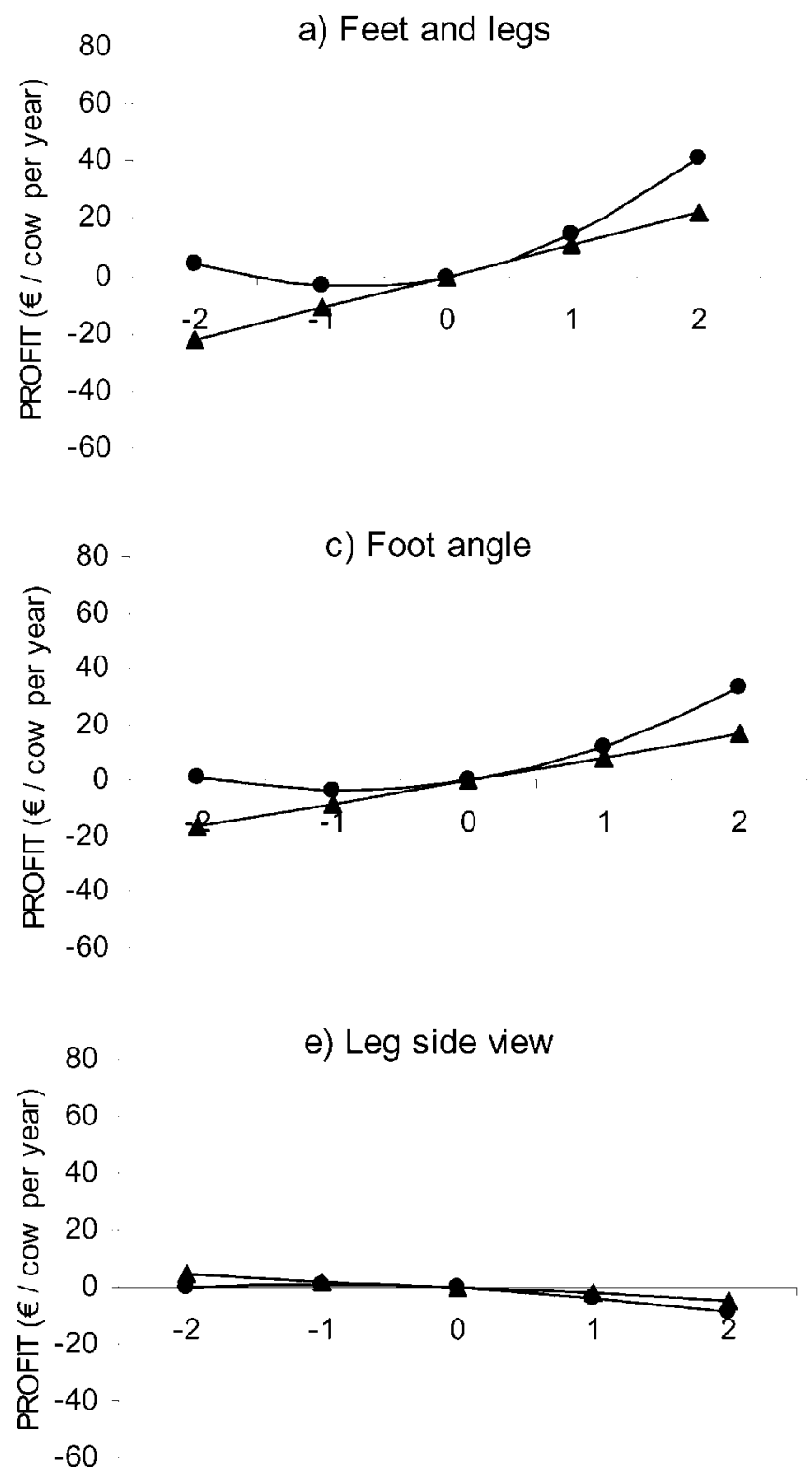

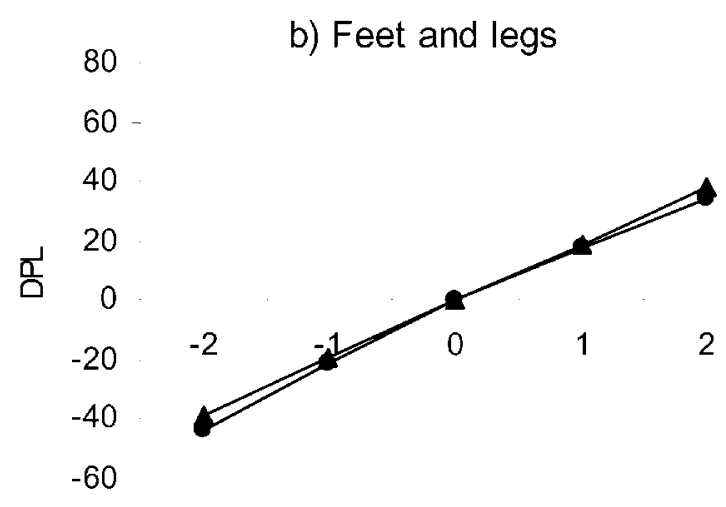

d) Foot angle
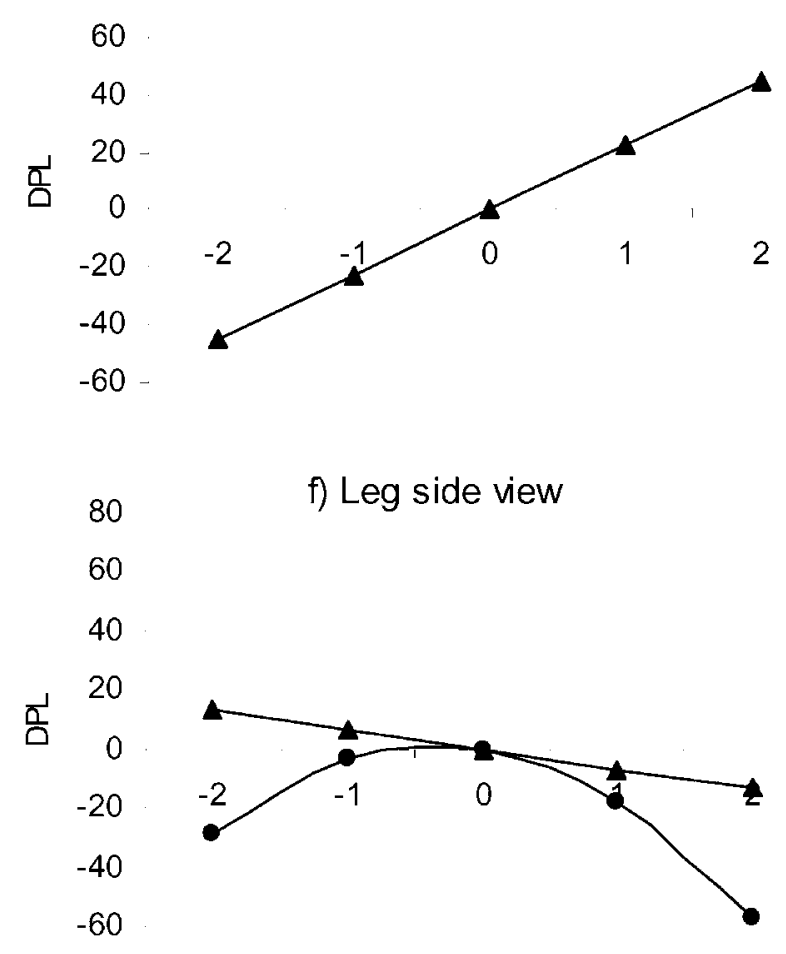

Figure 4. Significant linear $(\mathbf{A})$ and quadratic ( $)$ relationships between breeding values of profit (euros per cow and year) and days of productive life (DPL) adjusted for production traits, with feet and leg traits breeding values.

ure 5). However, quadratic coefficients were significant for the four udder traits individually. Rear-udder height and udder depth had similar graphic representations as feet and legs, but with less of a quantitative importance on profit, even though udder depth had the greatest influence in DPL (Figure 5j), probably because of their influence on health. Deep udders are associated with high-yielding cows, which are less often voluntarily culled (Larroque and Ducrocq, 1999), but they have higher risk of mastitis and sanitary disorders, which explains the reduced influence on profit. This is clearly shown in Figure $3 \mathrm{~g}$ and $\mathrm{h}$, where profit and days of productive life BV are predicted without production traits adjustment. Animals with deep udders are more profitable (due to a higher yield), but they remain for less time in herd because of udder disorders. If mastitis has been considered in the profit calculations (as loss of yield or extra health costs), graphical relationships between DPL and profit BV and udder traits could have different shapes.

Udder traits had less effect on profit than expected because they are highly correlated with production, and this study deals with profit regardless of production. An average of $5.5 \%$ of profit variability was explained 
a) Mammary system

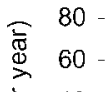

$$
\begin{aligned}
& \text { ญ } 40 \\
& \text { 总 } 20 \\
& \begin{array}{rr}
\frac{8}{0} & 0 \\
\underline{w} & -20 \\
\text { 눙 } & -40 \\
\text { 움 } & -60
\end{array}
\end{aligned}
$$

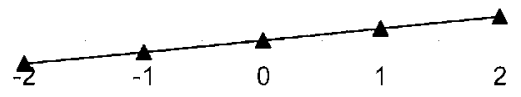

\begin{tabular}{ll}
80 \\
$\overbrace{\overline{\bar{D}}}$ & 60 \\
\hline & 40
\end{tabular}

c) Fore udder attachment

के 40

言 20

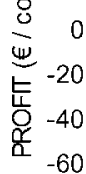

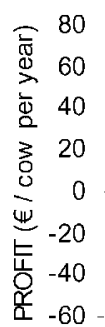

e) Rear udder height

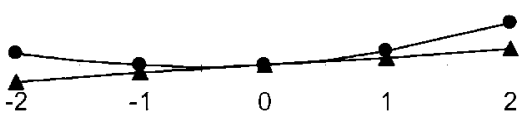

g) Suspensoryligament
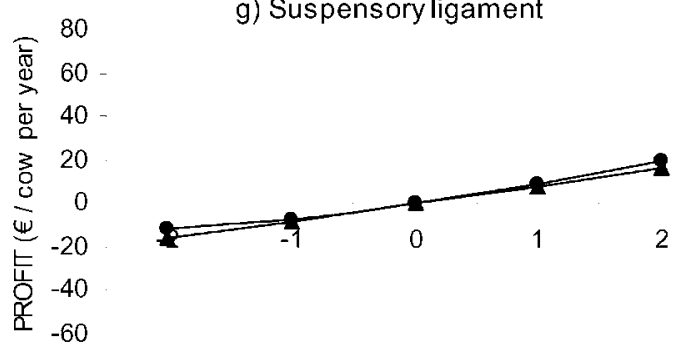

i) Udder depth

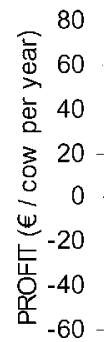

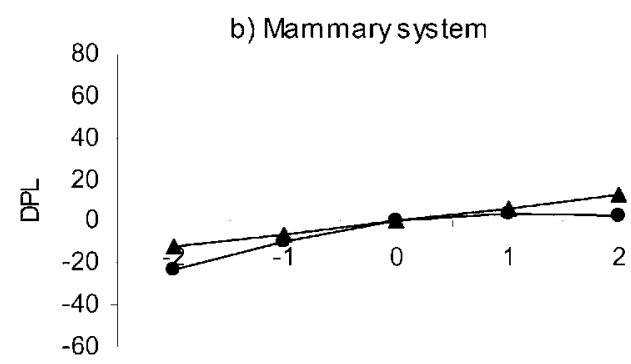

d) Fore udder attachement
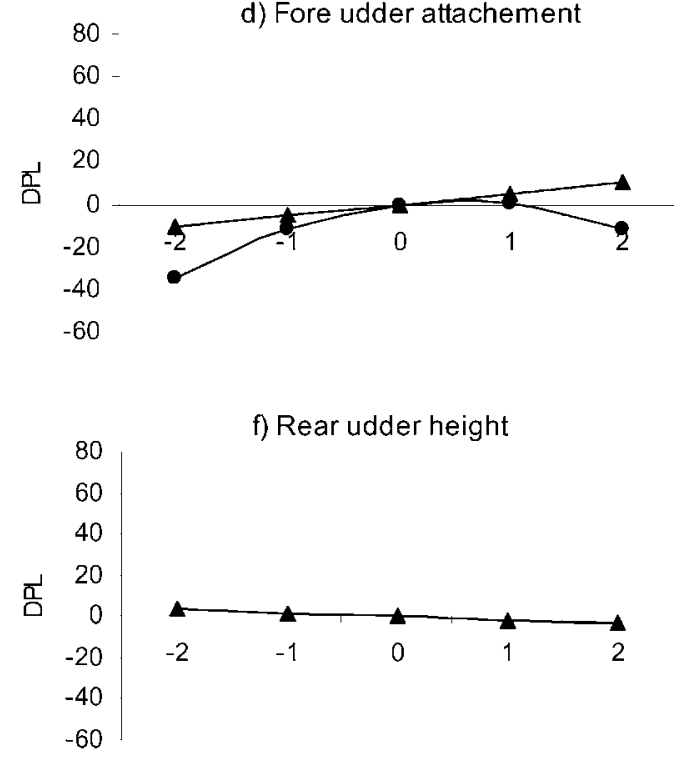

h) Suspensory ligament

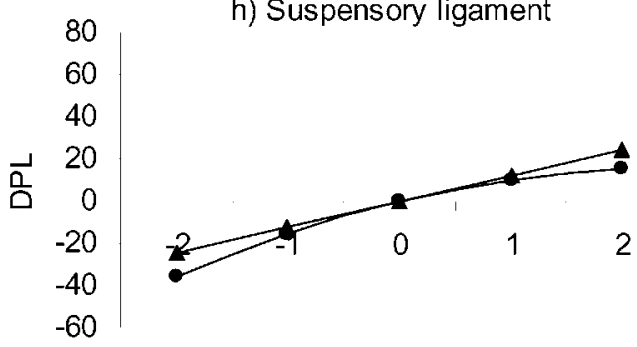

i) Udder depth

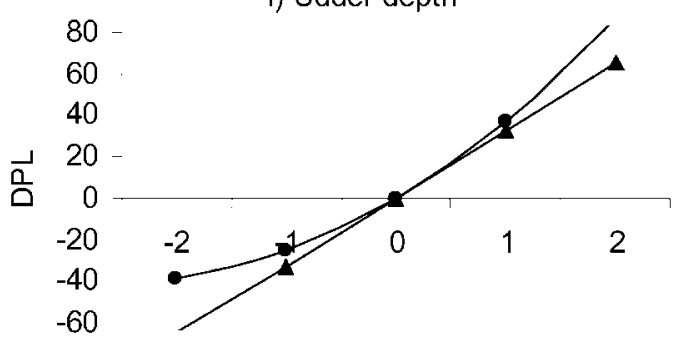

Figure 5. Significant linear $(\boldsymbol{\Delta})$ and quadratic (-) relationships between breeding values of profit (euros per cow and year) and days of productive life (DPL) adjusted for production traits, with udder traits breeding values. 
in the model with each udder trait, but $94.6 \%$ was removed if kilograms of milk, fat, and protein BV were considered in the model. For example, when profit was predicted from mammary system only $7.6 \%$ of total variation was explained. If, however, production is considered, $95.5 \%$ of the profit variability due to mammary system is eliminated.

\section{CONCLUSIONS AND APPLICATIONS}

Estimated heritability of profit was moderate (0.25) and suggests that it could be treated as a trait per se in future breeding programs. The highest genetic correlations with profit were obtained for suspensory ligament and rear-udder height, while slightly correlations were found for rump, capacity traits, leg side view, and feet and legs.

While udder traits were always considered the most influential on profit through longevity, this study has shown that they represent only half of what leg traits do, due to adjustment by production traits BV. Then, locomotive traits had the highest effect on profit BV followed by udder traits, and body traits scarcely affected it. The significant linear and quadratic relationship of udder depth with profit and DPL adjusted for production suggests that it should be taken into account in selection indexes, in order to consider udder health when the aim is improvement by profit.

Feet and legs BV influence profit BV despite the low heritability and low genetic correlation with profit shown in the literature and this study. This result is in agreement with producer thinking, which considers this trait an important criterion in their breeding strategy for profit improvement. As the significant quadratic adjustment showed, positive BV for feet and legs and foot angle have a positive influence on profit but not negative BV, despite the negative effect of bad legs on days of productive life $\mathrm{BV}$, probably due to other traits affecting profit. This result suggests that introducing feet and legs as a linear trait in a type-production index to improve functional longevity is correct, but that assumption is not correct with a profit improvement objective.

The highly significant quadratic relationships $(P<$ 0.0001 ) found between some type traits BV (feet and legs, foot angle, fore-udder attachment, rear-udder height and udder depth) and profit suggest that these adjustments must be dealt with in selection indexes, while others (final score, rump, mammary system, body depth, leg side view, mammary system, and suspensory ligament) should be considered linear. This work suggests that in future studies it may be of interest to consider other traits involved in profit, such as fertility and mastitis, and to look for their relationships with longevity and profit in order to include new traits in selection indexes.

\section{REFERENCES}

Brotherstone, S., C. M. McManus, and W. G. Hill. 1990. Estimation of genetic parameters for linear and miscellaneous type traits in Holstein-Friesian dairy cattle. Livest. Prod. Sci. 26:177-192.

Burke, B. P., and D. A. Funk. 1993. relationship of linear type traits and herd life under different management systems. J. Dairy Sci. 76:2773- 2778 .

Cassell, B. G., R. E. Pearson, J. Stoel, and S. Hiemstra. 1990. Relationships between sire evaluations for linear type traits and lifetime net income from grade and registered daughters. J. Dairy Sci. 73:198-204.

Charfeddine, N. 1998. Selección por mérito económico global en el ganado vacuno frisón en España. Tesis doctoral. Escuela Técnica Superior de Ingenieros Agrónomos, Univ. Politécnica Madrid.

Choi, Y. S., and B. T. McDaniel. 1993. Heritabilities of measures of hooves and their relation to other traits of Holsteins. J. Dairy Sci. 76:1989-1993.

Dekkers, J. C. M., L. K. Jairath, and B. H. Laurance. 1994. Relationships between sire genetic evaluation for conformation and functional herd life of daughters. J. Dairy Sci. 77: 844-854.

Essl, A. 1998. Longevity in dairy cattle breeding: a review. Livest. Prod. Sci. 57:79-89.

Groeneveld, E., and L. A. García Cortés. 1998. VCE 4.0, a (co)variance component package for frequentists and Bayesians. Proc. 6th. World Congress on Genetics Applied to Livestock Production. Vol. 27: 455-456.

Klassen, D. J., H. G. Monardes, R. I. Cue Jairath, and F. Hayes. 1992. Genetic correlations between lifetime production and linearized type in Canadian Holsteins. J. Dairy Sci. 75: 2272-2282.

Korver, S., J. A. M. Van Arendonk, and W. J. Koops. 1985. A function for liveweight change between two calvings in dairy cattle. Anim. Prod. 40:233.

Larroque, H., and V. Ducrocq. 1999. Phenotypic relationship between type and longevity in the Holstein breed. Proc. International Workshop on EU concerted action Genetic Improvement of Functional Traits in cattle; Longevity. Jouy-en-Josas, France. INTERBULL Bull. 21: 96-103.

McDaniel, B. T. 1997. Breeding programs to reduce foot and leg problems. Proc. International Workshop on Genetic Improvement of Functional Traits in cattle; Health. Uppsala, Sweden. INTERBULL Bull. 15:115-122.

Meyer, K., S. Brotherstone, W. G. Hill, and M. R. Edwards. 1987. Inheritance of linear type traits in dairy cattle and correlations with milk production. Anim. Prod. 44:1-10.

Norman, H. D., R. L. Powell, J. R. Wright, and B. G. Cassell. 1988. Phenotypic and genetic relationship between linear functional type traits and milk yield for five breeds. J. Dairy Sci. 71:1880-1896.

Norman, H. D., R. L. Powell, J. R. Wright, and R. E. Pearson. 1996. Phenotypic relationship of yield and type scores from first lactation with herd life and profitability. J. Dairy Sci. 79: 689-701.

Pérez, M. A., D. Hernández, R. Alenda, M. J. Carabaño, and N. Charfeddine. 1999. Genetic analysis of true profit for Spanish dairy cattle. Workshop on Genetic Improvement of Functional Traits in Cattle; Breeding Goals and Selection Schemes. Wageningen, The Netherlands, INTERBULL Bull. 23:107-113.

Rogers, G. W., G. L. Hargrove, J. B. Cooper, and E. P. Barton. 1991. Relationships among survival and linear type traits in Jerseys. J. Dairy Sci. 74:286-291.

Roxström, A., and E. Strandberg. 2002. Genetic analysis of functional, fertility-, mastitis-, and production-determined length of productive life in Swedish dairy cattle. Livest. Prod. Sci. 74:125-135.

SAS. User's Guide, Release 6.12. 1998. SAS Institute Inc., Cary, NC.

Schaeffer, L. R. 1983. Estimates of variance components for Holsteintype traits. Can. J. Anim. Sci. 63:763-771. 
Short, T. H., and T. J. Lawlor. 1992. Genetic parameters of conformation traits, milk yield, and herd life in Holsteins. J. Dairy Sci. 75:1987-1998.

Sölkner, J., and R. Petschina. 1999. Relationship between type traits and longevity in Austrian Simmental cattle. Proc. International Workshop on EU Concerted Action Genetic Improvement of Functional Traits in Cattle; Longevity. Jouy-en-Josas, France. INTERBULL Bull. 21:91-95.

Thompson, J. R., A. E. Freeman, D. J. Wilson, C. A. Chapin, P. J. Berger, and A. Kuck. 1981. Evaluation of a linear type program in Holsteins. J. Dairy Sci. 64:1610-1617.

Visscher, P. M., and M. E. Goddard. 1995a. Genetic analyses of profit for Australian dairy cattle. Anim. Sci. 61:9-18.
Visscher, P. M., and M. E. Goddard. 1995b. Genetic parameters for milk yield, survival, workability, and type traits for Australian dairy cattle. J. Dairy Sci. 78:205-220.

Vollema, Ant. R. 1998. Longevity of dairy cows: a review of genetic variances and covariances with conformation. Anim. Breed. Abstr. 66 (9):781-802.

Vukasinovic, N., J. Moll, and N. Künzi. 1995. Genetic relationships among longevity, milk production, and type traits in Swiss Brown cattle. Livest. Prod. Sci. 41:11-18.

Weigel, K. A., T. J. Jr. Lawlor, P. M. VanRaden, and G. R. Wiggans. 1998. Use of linear type and production data to supplement early predicted transmitting abilities for productive life. J. Dairy Sci. 81:2040-2044. 